\title{
Improving the Evaluation and Management of Cystotomy in Gynecologic Surgery with a Cadaver Surgical Curriculum
}

\author{
Cassandra Presti ${ }^{*}$, Conway Xu ${ }^{1}$, Chang Liu ${ }^{2}$, Larry Walker ${ }^{3}$, Lauren Scott ${ }^{1,4}$, \\ S. Abbas Shobeiri, ${ }^{1,4}$, Francine McLeod ${ }^{1}$ \\ ${ }^{1}$ Department of Obstetrics and Gynecology, Inova Fairfax Hospital, Falls Church, USA \\ ${ }^{2}$ Department of Surgery, Inova Fairfax Hospital, Falls Church, USA \\ ${ }^{3}$ Advanced Surgical Technology and Education Center, Inova Fairfax Hospital, Falls Church, USA \\ ${ }^{4}$ Division of Female Pelvic Medicine and Reconstructive Surgery, Inova Fairfax Hospital, Falls Church, USA \\ Email: *cassandra.presti@inova.org
}

How to cite this paper: Presti, C., Xu, C., Liu, C., Walker, L., Scott, L., Shobeiri, S.A. and McLeod, F. (2021) Improving the Evaluation and Management of Cystotomy in Gynecologic Surgery with a Cadaver Surgical Curriculum. Open Journal of $\mathrm{Ob}$ stetrics and Gynecology, 11, 1202-1216. https://doi.org/10.4236/ojog.2021.119114

Received: August 5, 2021

Accepted: September 21, 2021

Published: September 24, 2021

Copyright (๑) 2021 by author(s) and Scientific Research Publishing Inc. This work is licensed under the Creative Commons Attribution International License (CC BY 4.0).

http://creativecommons.org/licenses/by/4.0/

\begin{abstract}
Objectives: Urinary tract injuries are a known complication of gynecologic surgery, occurring in $0.18 \%-0.80 \%$ of procedures and most commonly involving the bladder. Appropriate identification, evaluation, treatment, and follow-up by gynecologic surgeons are important to reduce the associated long-term morbidities. The purpose of this study was to implement a comprehensive cadaver curriculum in cystotomy repair for OBGYN residents. Methods: This was a prospective observational cohort study including 10 OBGYN residents (PGY1-3) at a single institution in 2020 (56\% of the 18 eligible residents). The curriculum consisted of a one-hour didactic lecture and one-hour hands-on surgical skills training with fresh frozen cadavers. Residents were evaluated in three domains: 1) knowledge, 2) surgical skills, and 3) confidence. Knowledge, confidence, and resident satisfaction were evaluated with pre- and post-surveys. The bladder model, derived from the ACOG Simulation Working Group, was used to evaluate surgical skills at baseline and at completion of the curriculum. Results: Across all three PGY levels, statistically significant improvements were observed in knowledge, surgical skills, and confidence after didactic and cadaver education $(\mathrm{p}=0.001, \mathrm{p}<0.02$, and $p=0.009$ respectively). The largest increases in confidence occurred in residents' ability to describe and perform cystotomy repairs. Conclusions: Educating and training OBGYN residents to manage and repair cystotomies can be challenging given the low incidence of injury in the operating room. The cadaver surgical skills curriculum was an effective training module and remains an important component of skills training in conjunction with simulation and traditional didactic sessions.
\end{abstract}




\section{Keywords}

Bladder Injury, Cystotomy Repair, Cadaver Lab, Resident Curriculum

\section{Introduction}

Urinary tract injuries are a known complication of gynecologic surgery, occurring in $0.18 \%-0.80 \%$ of procedures [1] [2] [3]. Specifically, the most common injuries are to the bladder, accounting for $52 \%$ - 75\% of all urologic injuries [1] [2]. The rate of injury is higher in radical hysterectomies and pelvic floor surgeries. Although the overall incidence of intraoperative bladder injury has decreased in the last decade, gynecologic surgeries continue to account for the majority of bladder injuries [3] [4].

Appropriate identification, evaluation, treatment, repair, and follow-up by gynecologic surgeons are important to reduce the long-term morbidities associated with bladder injuries, including infection, fistulas, and renal damage [1] [2] [5]. Risk factors associated with cystotomies include prior cesarean delivery or other abdominal surgery, pelvic adhesions, endometriosis, distorted anatomy, and low-volume surgeons [2] [3] [5]. The general Obstetrician-Gynecologist (OBGYN) should be capable of selecting appropriate treatment based on size and location of injury including expectant management, prolonged use of a foley catheter, double-layer repair with delayed absorbable suture, or consultation with a urogynecology or urology specialist [3] [6] [7].

Therefore, training OBGYN residents to be skilled and confident in recognition and repair of uncomplicated bladder injuries is imperative [6]. In order to maximize operating room safety, these skills should be integrated into the surgical curriculum during residency. The low incidence of injury does not lend itself to adequate intra-operative training for residents. Didactic lectures and simulation models have previously been used as the foundation of surgical skills curriculum [8] [9]. Simulation has a vital role in the development and success of surgical training curricula [10] [11] [12] [13]. Prior studies in surgical training literature have analyzed cadaver labs for improved performance and trainee satisfaction [14]-[20]. The cadaver lab provides a cognitive simulation opportunity to train residents who may not receive adequate intra-operative training. The purpose of this study was to implement and evaluate a comprehensive cadaver and simulation skills training lab in cystotomy repair for OBGYN residents.

\section{Material and Methods}

\subsection{Curriculum Design}

This was a prospective observational cohort study conducted at a single academic medical center from March 2020 to May 2020. All curriculum sessions during the 6-week study period were held in the Advanced Surgical Technology and Education Center (ASTEC) at Inova Fairfax Hospital. The Institutional Re- 
view Board of the Inova Health System deemed the study as exempt.

The curriculum consisted of educational and hands-on surgical skills components. The one-hour didactic session presented a comprehensive overview of lower urinary tract injury: anatomy, sites of injury, diagnosis, surgical repair options, and outcomes. The surgical skills cadaver lab session utilized fresh frozen cadavers for a one-hour demonstration, feedback, and skills instruction by expert urogynecology faculty. The faculty to resident ratio of 1:4 maximized the learning environment. A defect was created in the bladder dome by the urogynecology faculty, residents observed a two-layer repair, and then performed a guided cystotomy repair of their own.

\subsection{Participants}

A baseline needs assessment was conducted as it pertains to anatomy, technical skill, and knowledge of urologic injuries. Senior residents were excluded from the study after this assessment was performed. Eligible participants included eighteen OBGYN residents, Postgraduate Year (PGY)1-3. Ten residents completed all portions of the study. Study demographics revealed one male and nine female participants composed of three PGY-1, four PGY-2, and three PGY-3 residents.

\subsection{Data Collection}

Residents were evaluated in three domains: knowledge, surgical skill, and confidence at baseline and six weeks post-curriculum (retention test). The knowledge, or cognitive, assessment included a written examination with a passing score of $75 \%$. This score was agreed upon by participating expert faculty and consistent with institutional standards [Appendix A]. The content of the written examination was presented during the didactic session and validated by expert faculty.

One urogynecologist performed all surgical skills assessments at baseline and six weeks post-curriculum. A low-fidelity bladder model adopted from the American College of Obstetricians and Gynecologists Simulation Working Group (Figure 1) was utilized during each assessment [21]. Two validated objective structured assessment of technical skill (OSATS) checklists were employed to assess surgical skill: the task specific checklist (TSC) [Appendix B] and the global rating scale (GRS) [Appendix C]. The internally validated TSC deconstructed the operative steps of a cystotomy repair and management. It incorporated points for identification of defect, anatomical layers, choice of suture material, assessment of bladder integrity, and follow up management. The GRS validated by Martin et al assessed global performance with a 5-point Likert scale in six domains: respect for tissue, time and motion, instrument handling, knowledge of instruments, flow of operation, and knowledge of specific procedure [22]. Within each domain, higher scores represented greater mastery of skill with the highest score assigned as 5. The final GRS score was the total score calculated from all domains. The maximum achievable score on both checklists was 30 . 


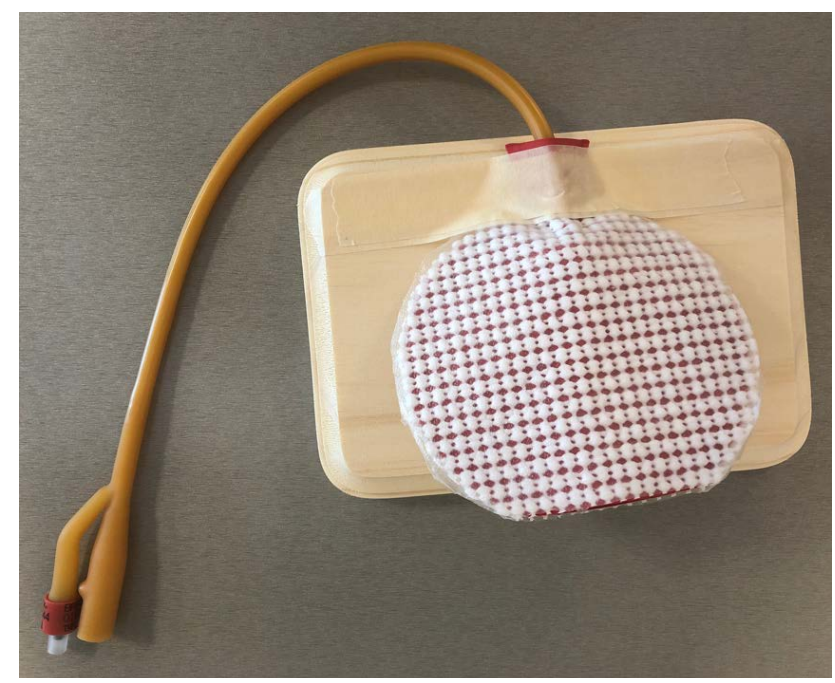

Figure 1. Bladder simulation model. This model was based on the American College of Obstetricians and Gynecologists Simulation Working Group model described by Braun et al. The layers of the bladder include serosa (Press'n Seal), muscularis (shelf liner), and mucosa (whoopee cushion). A foley catheter is inserted into the urethra and a cystotomy injury created in the dome of the bladder.

The faculty examiner assigned an overall "pass" or "fail" for each resident, based on a passing score of $75 \%$.

Resident confidence was assessed with a 5-point Likert scale questionnaire at baseline and post-curriculum. Higher scores were indicative of greater confidence in selected aspects of evaluation and management of bladder injuries [Appendix D]. Finally, at the completion of the curriculum, residents were asked to grade the course content, structure, and faculty [Appendix D].

\subsection{Data Analysis}

Individual scores were assigned for each resident in all domains. Pre- and post-curriculum scores were summarized using means with standard deviations and compared using paired t-test. All tests were two-sided and a p-value $<0.05$ was considered statistically significant. All analyses were performed in R 3.6.1 (R Core Team).

\subsection{Cost Analysis}

The total cost for one cadaver chest, abdomen, and pelvis was $\$ 2229.00$. The cost of the cadavers was divided evenly between the Departments of Surgery and Obstetrics and Gynecology for the training of residents. One cadaver was used for cystotomy repair training for $\$ 1114.50$, or approximately $\$ 111.45$ per resident (ten residents completed the cadaver curriculum). The American College of Obstetricians and Gynecologists' cystotomy simulator was approximately $\$ 1.50$ per model [21]. Each model was used twice with each resident, once for the pre-test and once for the post-test. The total curriculum expense was approximately $\$ 113$ 
per resident.

\section{Results}

Across all three PGY levels, knowledge improved nearly $25 \%$ after both didactic and cadaver education. In the 10-question evaluation of knowledge, $40 \%$ of residents passed in pre-testing while $90 \%$ passed after intervention.

Surgical skills improved significantly in post-curriculum evaluations. Comparison of pre and post-test skills evaluation in both the task specific and global rating scale scores are shown in Figure 2. The estimated mean scores with standard errors for both the task specific and global rating scale are depicted. When comparing pre and post-test results, residents demonstrated significant improvement. A statistically significant improvement was seen in the global rating scale scores. Overall, $60 \%$ of residents passed the skills pre-test, while $100 \%$ received a passing score after completing the curriculum. Table 1 presents the

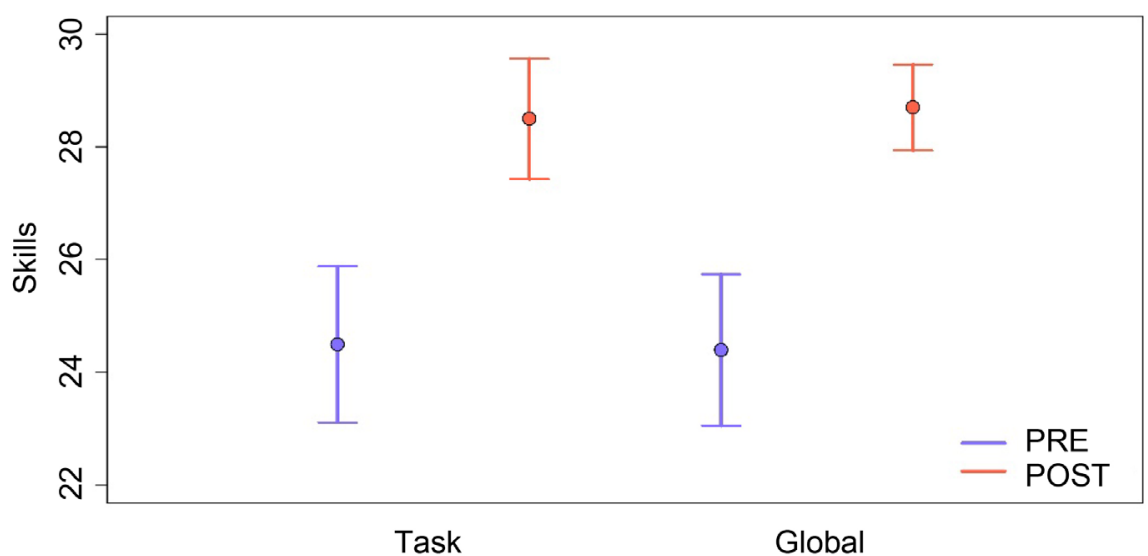

Figure 2. Overall resident surgical skills performance: task specific and global rating scale scores. The median scores on two validated objective structured assessment of technical skill (OSATS) checklists were calculated. The pre- (blue) and post- (red) cadaver lab scores for the task specific checklist (TSC) and global rating scale (GRS) are displayed. The median scores on the TSC were 24.5 and 28.5 and GRS were 24.4 and 28.7, for preand post-curriculum respectively.

Table 1. Evaluation of knowledge, confidence, and skills pre- and post-curriculum.

\begin{tabular}{clccc}
\hline & & \multicolumn{2}{c}{ Mean (SD) } & \multirow{2}{*}{ P-value } \\
\cline { 3 - 4 } Knowledge & & PRE & POST & \\
\hline \multirow{2}{*}{ Confidence } & Identification & $6.9(0.99)$ & $8.5(0.71)$ & 0.001 \\
& Repair dome & $2.5(1.18)$ & $3.8(0.79)$ & 0.009 \\
& Repair trigone & $1.8(1.03)$ & $4.1(0.88)$ & $<0.001$ \\
& Post-operative management & $2.6(1.17)$ & $4.2(0.79)$ & 0.001 \\
& Risk factors & $2.9(1.45)$ & $4(0.47)$ & 0.024 \\
\hline \multirow{2}{*}{ Skills } & Task Specific & $1.3(0.48)$ & $3(1.05)$ & $<0.001$ \\
& Global Rating Scale & $24.5(4.38)$ & $28.5(3.37)$ & 0.07 \\
& & $24.4(4.25)$ & $28.7(2.41)$ & 0.009 \\
\hline
\end{tabular}

$\mathrm{SD}$, Standard deviation. 
summaries and comparisons between pre- and post-curriculum for all assessment domains. Significant improvement was observed post training in all domains except for TSC checklist, for which the extent of improvement was still remarkable and trending towards significance.

Residents consistently showed high satisfaction and improvement in confidence with the cystotomy curriculum. There was a statistically significant improvement in confidence in all areas-identifying an injury and risk factors for cystotomy, as well as describing the basic steps in performing repairs and managing them post-operatively. The largest increases occurred in residents' ability to describe and perform cystotomy repairs.

Participant satisfaction was evaluated at the end of the curriculum and after all skills evaluations were completed. At baseline, $100 \%$ of residents felt that they needed additional training in cystotomy repair. Post-curriculum, 100\% of residents felt the session not only reinforced their skills, but also introduced new techniques. The overall grade assigned to the curriculum was "A" by $90 \%$ of residents.

\section{Discussion}

The incidence of bladder injuries in obstetrics and gynecology is low and has decreased over time [1] [2] [3] [4]. However, when bladder injuries occur, they can be a source of significant stress due to the medical, socio-economical, and legal implications. Clinically, bladder injuries are associated with increased operative time, return to the operating room, need for prolonged indwelling catheters, urinary tract infections, fistula formation, and loss of renal function [4]. Cystotomies can also lead to temporary or permanent loss of employment, anxiety, depression, and deterioration of interpersonal relationships [23]. Furthermore, lower urinary tract injuries are the most common reasons for litigation in OBGYN, and physicians involved may experience significant personal and financial costs related to litigation [23]. Given that bladder injuries have such low incidence, traditional OBGYN residency training may not provide adequate exposure for trainees. With the significant implications in mind when bladder injuries do occur, this study demonstrated that the cadaver surgical skills training curriculum greatly improved residents' knowledge, surgical skills, and confidence to properly identify and repair bladder injuries. Each of these iscrucial to successful clinical practice and enhancing patient care when cystotomies occur. Furthermore, all participants showed good retention of knowledge and skills 6 weeks after training session on the simulation model.

Cadaveric dissection has been well-established as an educational tool in medical education. While there have been many studies within OBGYN that have embraced this modality for continued research and competency training, none have focused on the repair of bladder injuries. Studies to date have focused on urogynecologic procedures [20] [24] [25] [26] [27] [28], general surgical anatomy in OBGYN [29], complex dissection and management of surgical complica- 
tions in gynecologic oncology fellow education [18] [30] [31] [32] [33], preparing medical students for internship [34] [35], general laparoscopic surgical techniques [19] [36], and management of severe peripartum lacerations or bleeding [37] [38] [39]. The lack of prior studies focusing on resident education and management of bladder injuries further highlights the importance of this cohort study.

Strengths of this study include its prospective nature, as well as the multi-modal validated assessment of the effect of the cadaver curriculum. To our knowledge, this is the first study to introduce and evaluate educational curricula using cadavers for cystotomy repair training. Simulation was combined with a traditional cadaver laboratory in a multi-step process. Residents were able to adapt to these different "bladder environments" with great confidence. When paired together, the cadaver provided the most authentic tissue handling, while the simulator was durable and reusable. Additionally, our curriculum is generalizable to any training program with the resources, time, and availability of surgical educators.

The principal limitation is sample size. The coronavirus disease 2019 (COVID19) pandemic limited our ability to facilitate residency wide in-person trainings. Therefore, our study utilized the available resident cohort for study outcome measures. Even though the number of participants limited our results, the educational impact of the curriculum remained measurable.

The cost of obtaining fresh frozen cadavers could be a rate-limiting factor for use of this curriculum in some institutions. In order to propose the use of this curriculum at outside institutions, they must have access or the ability to afford cadaver lab trainings. Our institution cost-shared with the Department of Surgery using cadaver torsos, purchased at approximately $\$ 2229.00$ per cadaver. Alternatively, a cadaver pelvis could be purchased at a lower price (approximately $\$ 1769.00$ ) as only the pelvis was utilized for this curriculum. The simulation toolkit was easily accessible and affordable, at approximately $\$ 1.50$ per model [21]. Cost sharing between the Departments of Surgery and Obstetrics and Gynecology at our institution decreased the financial burden of the cadaver lab. The cadaver lab session has become an annual integral part of resident education, and therefore, this particular study required no additional funding at our institution.

Finally, no formal intraoperative assessment of learned skills was performed. The incidence of bladder injury during gynecologic surgery at our institution is comparable to national standards. As such, we were unable to examine the final level of the Kirkpatrick Model during the study period. Teaching the fundamental technical and surgical skills with subsequent demonstration with patient care should be an area of continued focus and research.

\section{Conclusion}

Educating and training OBGYN residents to manage and repair cystotomies can 
be challenging given the low incidence of injury and minimal intra-operative training. With the changing landscape of surgical education, duty hour restrictions, and shift in paradigm toward patient safety, simulation has emerged as a key component of many surgical skills curricula. Maximizing competency and proficiency outside of the operating room has facilitated efficiency and confidence by trainees inside the operating room. Further research is needed that combines the cadaver lab with simulation models for maximal training potential, particularly when injuries of low incidence and high morbidity can impact women's health care. The cadaver lab remains an important component in surgical skills training, in conjunction with traditional didactic lectures and simulation training.

\section{Acknowledgements}

The authors would like to thank the Advanced Surgical Technology and Education Center for cadaver sessions and facilities. We would also like to express our appreciation to the American College of Obstetricians and Gynecologists Simulation Working Group for the Cystotomy Model (Washington, DC, USA).

\section{Funding}

This research did not receive any specific grant from funding agencies in the public, commercial, or not-for-profit sectors.

\section{Conflicts of Interest}

The authors declare no conflicts of interest regarding the publication of this paper.

\section{References}

[1] Satitniramai, S. and Manonai, J. (2017) Urologic Injuries during Gynecologic Surgery: A 10-Year Review. Journal of Obstetrics and Gynaecology Research, 43, 557-563. https://doi.org/10.1111/jog.13238

[2] Wong, J.M.K., Bortoletto, P., Tolentino, J., Jung, M.J. and Milad, M.P. (2018) Urinary Tract Injury in Gynecologic Laparoscopy for Benign Indication: A Systematic Review. Obstetrics \& Gynecology, 131, 100-108.

https://doi.org/10.1097/AOG.0000000000002414

[3] Glaser, L.M. and Milad, M.P. (2019) Bowel and Bladder Injury Repair and Follow-Up after Gynecologic Surgery. Obstetrics \& Gynecology, 133, 313-322. https://doi.org/10.1097/AOG.0000000000003067

[4] Frankman, E.A., Wang, L., Bunker, C.H. and Lowder, J.L. (2010) Lower Urinary Tract Injury in Women in the United States, 1979-2006. American Journal of $O b$ stetrics \& Gynecology, 202, 495.e1-495.e5. https://doi.org/10.1016/j.ajog.2010.01.013

[5] Sharp, H.T. and Adelman, M.R. (2016) Prevention Recognition and Management of Urologic Injuries during Gynecologic Surgery. Obstetrics \& Gynecology, 127, 10851096. https://doi.org/10.1097/AOG.0000000000001425

[6] Findley, A.D. and Solnik, M.J. (2016) Prevention and Management of Urologic In- 
jury during Gynecologic Laparoscopy. Current Opinion in Obstetrics and Gynecology, 28, 323-328. https://doi.org/10.1097/GCO.0000000000000296

[7] Kaestner, L. (2019) Management of Urological Injury at the Time of Urogynaecology Surgery. Best Practice \& Research Clinical Obstetrics \& Gynaecology, 54, 2-11. https://doi.org/10.1016/j.bpobgyn.2018.06.007

[8] Kim-Fine, S. and Brennard, E.A. (2016) Surgical Simulation and Competency. $O b$ stetrics and Gynecology Clinics of North America, 43, 575-590. https://doi.org/10.1016/j.ogc.2016.04.007

[9] Kolozsvari, N.O., Feldmand, L.S., Vassiliou, M.C., Demyttenaere, S. and Hoover, M.L. (2011) Sim One, Do One, Teach One: Consideration in Designing Training Curricula for Surgical Simulation. Journal of Surgical Education, 68, 421-427. https://doi.org/10.1016/j.jsurg.2011.03.010

[10] Windsor, J.A. (2009) Role of Simulation in Surgical Education and Training. $A N Z$ Journal of Surgery, 79, 127-132. https://doi.org/10.1111/j.1445-2197.2008.04829.x

[11] McClusky, D.A. and Smith, C.D. (2008) Design and Development of a Surgical Skill Simulation Curriculum. World Journal of Surgery, 32, 171-181.

https://doi.org/10.1007/s00268-007-9331-9

[12] Aggarwal, R., Grantcharov, T.P. and Darzi, A. (2007) Framework for Systematic Training and Assessment of Technical Skill. Journal of the American College of Surgeons, 204, 697-705. https://doi.org/10.1016/j.jamcollsurg.2007.01.016

[13] Sturm, L.P., Windsor, J.A., Cosman, P.H., Cregan, P., Hewett, P.J. and Maddern, G.J. (2008) A Systematic Review of Skills Transfer after Surgical Simulation Training. Annals of Surgery, 248, 166-179. https://doi.org/10.1097/SLA.0b013e318176bf24

[14] Sharma, M., Macafee, D. and Horgan, A.F. (2013) Basic Laparoscopic Skills Training Using Fresh Frozen Cadaver: A Randomized Controlled Trial. American Journal of Surgery, 206, 23-31. https://doi.org/10.1016/j.amjsurg.2012.10.037

[15] Giger, U., Fresard, I., Haflinger, A., Bergmann, M. and Krähenbühl, L. (2008) Laparoscopic Training on Thiel Human Cadavers: A Model to Teach Advanced Laparoscopic Procedures. Surgical Endoscopy, 22, 901-906.

https://doi.org/10.1007/s00464-007-9502-7

[16] Supe, A., Dalvi, A., Prabhu, R., Kantharia, C. and Bhuiyan, P. (2005) Cadaver Model for Laparoscopic Training. Indian Journal of Gastroenterology, 24, 111-113.

[17] Reed, A.B., Crafton, C., Giglia, J.S. and Hutto, J.D. (2009) Back to Basics: Use of Fresh Cadavers in Vascular Surgery Training. Surgery, 146, 757-763.

https://doi.org/10.1016/j.surg.2009.06.048

[18] Barton, D.P.J., Davies, D.C., Mahadevan, C., Dennis, L., Adib, T., Mudan, S., et al. (2009) Dissection of Soft-Preserved Cadavers in the Training of Gynaecological Oncologists: Report of the First UK Workshop. Gynecologic Oncology, 113, 352-356. https://doi.org/10.1016/j.ygyno.2009.02.012

[19] Lim, C.P., Roberts, M., Chalhoub, T., Waugh, J. and Delgaty, L. (2018) Cadaveric Surgery in Core Gynaecology Training: A Feasibility Study. Gynecological Surgery, 15, Article No. 4. https://doi.org/10.1186/s10397-017-1034-0

[20] Chong, W., Downing, K., Leegant, A., Banks, E., Fridman, D. and Downie, S. (2017) Resident Knowledge, Surgical Skill, and Confidence in Transobturator Vaginal Tape Placement: The Value of a Cadaver Laboratory. Female Pelvic Medicine \& Reconstructive Surgery g, 23, 392-400. https://doi.org/10.1097/SPV.0000000000000458

[21] Braun, K., Ray, C., Stager, R. and Rungruang, B. (2018) Teaching Cystotomy Repair: 
Low Fidelity Model Provides Effective Simulation at Minimal Cost. Obstetrics \& Gynecology, 122, 43S. https://doi.org/10.1097/01.AOG.0000546625.12433.e2

[22] Martin, J.A., Regehr, G., Reznick, R., Macrae, H., Murnaghan, J., Hutchison, C., et al. (1997) Objective Structured Assessment of Technical Skill (OSATS) for Surgical Residents. BJS (British Journal of Surgery), 84, 273-278. https://doi.org/10.1046/j.1365-2168.1997.02502.x

[23] Gilmour, D.T. and Baskett, T.F. (2005) Disability and Litigation from Urinary Tract Injuries at Benign Gynecologic Surgery in Canada. Obstetrics \& Gynecology, 105, 109-114. https://doi.org/10.1097/01.AOG.0000144127.78481.8c

[24] Akar, B., Aslancan, R., Dogan, O., Sivaslıŏlu, A. and Çalışkan, E. (2020) The Effect of Hands-On Cadaver and Live Surgery Practice on Surgeons' Performance in Urogynecologic Operations: One-Year Follow-Up. Journal of Gynecologic Surgery, 36, 41-46. https://doi.org/10.1089/gyn.2019.0041

[25] Zahn, C.M., Siddique, S., Hernandez, S. and Lockrow, E.G. (2007) Anatomic Comparison of Two Transobturator Tape Procedures. Obstetrics \& Gynecology, 109, 701-706. https://doi.org/10.1097/01.AOG.0000255662.79008.18

[26] Neuman, M., Masata, J., Hubka, P., Bornstein, J. and Martan, A. (2012) Sacrospinous Ligaments Anterior Apical Anchoring for Needle-Guided Mesh Is a Safe Option: A Cadaveric Study. Urology, 79, 1020-1022. https://doi.org/10.1016/j.urology.2012.01.045

[27] Bonnet, P., Waltregny, D., Reul, O. and de Leval, J.E. (2005) Transobturator Vaginal Tape Inside Out for the Surgical Treatment of Female Stress Urinary Incontinence: Anatomical Considerations. Journal of Urology, 173, 1223-1228. https://doi.org/10.1097/01.ju.0000148364.13525.7b

[28] Masata, J., Hubka, P. and Martan, A. (2012) Pudendal Neuralgia Following Transobturator Inside-Out Tape Procedure (TVT-O)-Case Report and Anatomical Study. International Urogynecology Journal, 23, 505-507. https://doi.org/10.1007/s00192-011-1555-4

[29] Corton, M.M., Wai, C.Y., Vakili, B., Boreham, M.K., Schaffer, J.I. and Coleman, R.L. (2003) A Comprehensive Pelvic Dissection Course Improves Obstetrics and Gynecology Resident Proficiency in Surgical Anatomy. American Journal of Obstetrics \& Gynecology, 189, 647-651. https://doi.org/10.1067/S0002-9378(03)00881-0

[30] Nakamura, M., Fujii, T., Imanishi, N., Jinzaki, M., Yamada, M., Kuribayashi, S., et al. (2014) Surgical Anatomy Imaging Associated with Cervical Cancer Treatment: A Cadaveric Study. Clinical Anatomy, 27, 503-510. https://doi.org/10.1002/ca.22319

[31] Barksdale, P.A., Brody, S.P., Garely, A.D., Elkins, T.E., Nolan, T.E. and Gasser, R.F. (1997) Surgical Landmarks of the Ureter in the Cadaveric Female Pelvis. Clinical Anatomy, 10, 324-327. https://doi.org/10.1002/(SICI)1098-2353(1997)10:5\%3C324::AID-CA6\%3E3.0.CO;2-Q

[32] Hammond, I., Taylor, J., Obermair, A. and McMenamin, P. (2004) The Anatomy of Complications Workshop: An Educational Strategy to Improve the Training and Performance of Fellows in Gynecologic Oncology. Gynecologic Oncology, 94, 769-773. https://doi.org/10.1016/j.ygyno.2004.06.022

[33] Kraima, A.C., Derks, M., Smit, N.N., van de Velde, C.J.H., Kenter, G.G. and DeRuiter, M.C. (2016) Careful Dissection of the Distal Ureter Is Highly Important in Nerve-Sparing Radical Pelvic Surgery: A 3D Reconstruction and Immunohistochemical Characterization of the Vesical Plexus. International Journal of Gynecologic Cancer, 26, 959-966. https://doi.org/10.1097/IGC.0000000000000709

[34] Morgan, H., Marzano, D., Lanham, M., Stein, T., Curran, D. and Hammoud, M. 
(2014) Preparing Medical Students for Obstetrics and Gynecology Milestone Level One: A Description of a Pilot Curriculum. Medical Education Online, 19, Article ID: 25746. https://doi.org/10.3402/meo.v19.25746

[35] Goldman, E.M., Wydo, S., Green, R., Huff, S. and Germaine, P. (2018) A Pre-Surgical Residency Refresher Course That Advances Students from the Cadaver Lab to the Surgical Suite. Medical Science Educator, 28, 227-234. https://doi.org/10.1007/s40670-017-0503-4

[36] Levine, R.L., Kives, S., Cathey, G., Blinchevsky, A., Acland, R., Thompson, C., et al. (2006) The Use of Lightly Embalmed (Fresh Tissue) Cadavers for Resident Laparoscopic Training. Journal of Minimally Invasive Gynecology, 13, 451-456. https://doi.org/10.1016/j.jmig.2006.06.011

[37] Kerbage, Y., Debarge, V., Lucot, J.P., Clouqueur, E. and Rubod, C. (2016) Simulation Training to Teach Postpartum Hemorrhage Surgery to Residents. European Journal of Obstetrics \& Gynecology, 201, 27-30.

https://doi.org/10.1016/j.ejogrb.2016.03.013

[38] Selçuk, İ., Yassa, M., Tatar, İ. And Huri, E. (2018) Anatomic Structure of the Internal Iliac Artery and Its Educative Dissection for Peripartum and Pelvic Hemorrhage. Turkish Journal of Obstetrics and Gynecology, 15, 126-129. https://doi.org/10.4274/tjod.23245

[39] Emmanuelli, V., Lucot, J.P., Closset, E., Cosson, M. and Deruelle, P. (2013) Development and Assessment of a Workshop on Repair of Third and Fourth Degree Obstetric Tears. Journal de Gynécologie Obstétrique et Biologie de la Reproduction, 42, 184-190. https://doi.org/10.1016/j.jgyn.2012.12.011 


\section{Supplemental Files}

\section{Appendix A. Cystotomy Knowledge Evaluation}

1) The most common site of bladder injury is:
a) Dome
b) Trigone
c) Posterior wall
d) Bladder neck

2) The incidence of bladder injury during gynecologic surgery is:
a) $0.01 \%$
b) $0.1 \%$
c) $1.0 \%$
d) $2.0 \%$

3) Cystoscopy is always needed to evaluate to bladder during or after repair.
a) TRUE
b) FALSE

4) The blood supply to the bladder mainly comes from:
a) Internal iliac artery
b) External iliac artery
c) Uterine Artery
d) Femoral Artery

5) The best time to repair a bladder injury is:
a) At time of diagnosis
b) After placing ureteral stents
c) After urology/urogynecology consultation
d) After bladder layers have healed

6) Bladder injuries always need to be repaired as there is risk of enlargement of the defect and weakening of bladder muscle.
a) TRUE
b) FALSE

7) The appropriate suture for bladder repair is:
a) Chromic
b) Vicryl
c) Silk
d) PDS

8) Prior to removal of the foley catheter, what test should be performed?
a) Bladder scan
b) Post void residual volume
c) CT urogram
d) MRI pelvis

9) Most common gynecologic surgery accounting for bladder injury is?
a) Total abdominal hysterectomy
b) Total laparoscopic hysterectomy
c) Total vaginal hysterectomy 
d) Robotic assisted total hysterectomy

10) Which of the following is a form of secondary prevention for bladder injuries?

a) Placing a foley catheter intraoperatively

b) Identification of bladder anatomy intraoperatively

c) Identification of cystotomy with cystoscopy intraoperatively

d) Identification of cystotomy with CT urogram post-operatively

\section{Appendix B. Cystotomy Task Specific Check List}

\begin{tabular}{|c|c|c|c|}
\hline 1) Correctly identifies the injury site & YES & NO & (5 points) \\
\hline $\begin{array}{l}\text { 2) Correctly identifies all of the layers } \\
\text { of bladder }\end{array}$ & YES & NO & (5 points) \\
\hline 3) Uses appropriate suture for repair & YES & NO & (5 points) \\
\hline 4) Performs double-layer closure & YES & NO & (5 points) \\
\hline 5) Checks integrity of repair & YES & NO & (5 points) \\
\hline 6) Correctly manages foley catheter/post-op care & YES & NO & (5 points) \\
\hline Total & & & 30 \\
\hline
\end{tabular}


Appendix C. Cystotomy Repair Global Rating Scale

\begin{tabular}{|c|c|c|c|c|c|}
\hline $\begin{array}{l}\text { Respect for } \\
\text { tissue }\end{array}$ & $\begin{array}{l}1 \\
\text { Frequently used } \\
\text { unnecessary force } \\
\text { on tissue or } \\
\text { caused damage by } \\
\text { inappropriate use } \\
\text { of instruments }\end{array}$ & 2 & $\begin{array}{l}3 \\
\text { Careful handling } \\
\text { of tissue but } \\
\text { occasionally } \\
\text { caused } \\
\text { inadvertent } \\
\text { damage }\end{array}$ & 4 & $\begin{array}{l}5 \\
\text { Consistently } \\
\text { handled tissues } \\
\text { appropriately } \\
\text { with minimal } \\
\text { damage }\end{array}$ \\
\hline $\begin{array}{l}\text { Time and } \\
\text { motion }\end{array}$ & $\begin{array}{l}1 \\
\text { Many } \\
\text { unnecessary } \\
\text { moves }\end{array}$ & 2 & $\begin{array}{l}3 \\
\text { Efficient } \\
\text { time/motion but } \\
\text { some } \\
\text { unnecessary } \\
\text { moves }\end{array}$ & 4 & $\begin{array}{l}5 \\
\text { Economy of } \\
\text { movement and } \\
\text { maximum } \\
\text { efficiency }\end{array}$ \\
\hline $\begin{array}{l}\text { Instrument } \\
\text { handling }\end{array}$ & $\begin{array}{l}1 \\
\text { Repeatedly makes } \\
\text { tentative or } \\
\text { awkward moves } \\
\text { with instruments }\end{array}$ & 2 & $\begin{array}{l}3 \\
\text { Competent use } \\
\text { of instruments } \\
\text { although } \\
\text { occasionally } \\
\text { appeared stiff } \\
\text { or awkward }\end{array}$ & 4 & $\begin{array}{l}5 \\
\text { Fluid moves with } \\
\text { instruments and } \\
\text { no awkwardness }\end{array}$ \\
\hline $\begin{array}{l}\text { Knowledge } \\
\text { of } \\
\text { instruments }\end{array}$ & $\begin{array}{l}1 \\
\text { Frequently asked } \\
\text { for the wrong } \\
\text { instrument or } \\
\text { used an } \\
\text { inappropriate } \\
\text { instrument }\end{array}$ & 2 & $\begin{array}{l}3 \\
\text { Knew the names } \\
\text { of most } \\
\text { instruments and } \\
\text { used appropriate } \\
\text { instrument for } \\
\text { the task }\end{array}$ & 4 & $\begin{array}{l}5 \\
\text { Obviously famili- } \\
\text { ar with the } \\
\text { instruments } \\
\text { required and } \\
\text { their names }\end{array}$ \\
\hline $\begin{array}{l}\text { Flow of } \\
\text { operation } \\
\text { and forward } \\
\text { planning }\end{array}$ & $\begin{array}{l}1 \\
\text { Frequently } \\
\text { stopped operating } \\
\text { or needed to } \\
\text { discuss next move }\end{array}$ & 2 & $\begin{array}{l}3 \\
\text { Demonstrate } \\
\text { ability for } \\
\text { forward } \\
\text { planning with } \\
\text { steady } \\
\text { progression of } \\
\text { operative } \\
\text { procedure }\end{array}$ & 4 & $\begin{array}{l}5 \\
\text { Obviously } \\
\text { planned course of } \\
\text { operation with } \\
\text { effortless flow } \\
\text { from one move to } \\
\text { the next }\end{array}$ \\
\hline $\begin{array}{l}\text { Knowledge } \\
\text { of specific } \\
\text { procedure }\end{array}$ & $\begin{array}{l}1 \\
\text { Deficient } \\
\text { knowledge. } \\
\text { Needed specific } \\
\text { instruction at } \\
\text { most operative } \\
\text { steps }\end{array}$ & 2 & $\begin{array}{l}3 \\
\text { Knew all } \\
\text { important } \\
\text { aspects of the } \\
\text { operation }\end{array}$ & 4 & $\begin{array}{l}5 \\
\text { Demonstrated } \\
\text { familiarity with } \\
\text { all aspects of the } \\
\text { operation }\end{array}$ \\
\hline $\begin{array}{l}\text { Overall score } \\
\text { (out of } 30 \text { ) }\end{array}$ & $\begin{array}{l}\text { Overall, should } \\
\text { this resident }\end{array}$ & PASS & FAIL & & \\
\hline
\end{tabular}




\section{Appendix D. Cystotomy Repair Confidence and Satisfaction} Evaluation

PRE

\begin{tabular}{|c|c|c|c|c|c|}
\hline \multirow{2}{*}{ Self-Assessment of Skills/Tasks } & \multirow{2}{*}{$\begin{array}{c}\begin{array}{c}\text { Not } \\
\text { Confident }\end{array} \\
1\end{array}$} & \multicolumn{3}{|c|}{$\begin{array}{l}\text { Somewhat } \\
\text { Confident }\end{array}$} & \multirow{2}{*}{$\begin{array}{c}\text { Completely } \\
\text { Confident } \\
5\end{array}$} \\
\hline & & 2 & 3 & 4 & \\
\hline $\begin{array}{l}\text { Describe how to locate and confirm a } \\
\text { bladder injury }\end{array}$ & $\square$ & $\square$ & $\square$ & $\square$ & $\square$ \\
\hline $\begin{array}{l}\text { Describe the basic steps in performing a } \\
\text { repair of an injury to the bladder dome }\end{array}$ & $\square$ & $\square$ & 口 & $\square$ & $\square$ \\
\hline $\begin{array}{l}\text { Describe the basic steps in performing a } \\
\text { repair of an injury to the bladder trigone }\end{array}$ & $\square$ & $\square$ & 口 & $\square$ & $\square$ \\
\hline $\begin{array}{l}\text { Describe the postoperative management } \\
\text { after cystotomy repair }\end{array}$ & $\square$ & $\square$ & $\square$ & $\square$ & $\square$ \\
\hline $\begin{array}{l}\text { Describe risk factors for cystotomy } \\
\text { during gynecologic surgery }\end{array}$ & $\square$ & $\square$ & $\square$ & $\square$ & $\square$ \\
\hline
\end{tabular}

POST

\begin{tabular}{|c|c|c|c|c|c|}
\hline \multirow[t]{2}{*}{ Self-Assessment of Skills/Tasks } & \multirow{2}{*}{$\begin{array}{c}\begin{array}{c}\text { Not } \\
\text { Confident }\end{array} \\
1\end{array}$} & \multicolumn{2}{|c|}{$\begin{array}{l}\text { Somewhat } \\
\text { Confident }\end{array}$} & \multicolumn{2}{|c|}{$\begin{array}{r}\text { Completely } \\
\text { Confident }\end{array}$} \\
\hline & & 2 & 3 & & 5 \\
\hline $\begin{array}{l}\text { Describe how to locate and confirm a } \\
\text { bladder injury }\end{array}$ & $\square$ & $\square$ & $\square$ & & $\square$ \\
\hline $\begin{array}{l}\text { Describe the basic steps in performing a } \\
\text { repair of an injury to the bladder dome }\end{array}$ & $\square$ & $\square$ & $\square$ & & $\square$ \\
\hline $\begin{array}{l}\text { Describe the basic steps in performing a } \\
\text { repair of an injury to the bladder trigone }\end{array}$ & $\square$ & $\square$ & $\square$ & & $\square$ \\
\hline $\begin{array}{l}\text { Describe the postoperative management after } \\
\text { cystotomy repair }\end{array}$ & $\square$ & $\square$ & $\square$ & & $\square$ \\
\hline $\begin{array}{l}\text { Describe risk factors for cystotomy during } \\
\text { gynecologic surgery }\end{array}$ & $\square$ & $\square$ & $\square$ & & $\square$ \\
\hline Session Evaluation & & & YES & No & N/A \\
\hline Have you performed a cystotomy repair in the & perating room? & & $\square$ & $\square$ & $\square$ \\
\hline $\begin{array}{l}\text { Have you observed a specialist perform a cysto } \\
\text { operating room? }\end{array}$ & my repair in the & & $\square$ & $\square$ & $\square$ \\
\hline Do you feel you need additional training? & & & $\square$ & $\square$ & $\square$ \\
\hline Did this session reinforce your current skills & & & $\square$ & $\square$ & $\square$ \\
\hline Did this session expose you to new skills/techn & jues? & & $\square$ & $\square$ & $\square$ \\
\hline Did you receive feedback during this session? & & & $\square$ & $\square$ & $\square$ \\
\hline Did faculty allow adequate time for discussion & nd questions? & & $\square$ & $\square$ & $\square$ \\
\hline Please grade this course: & $\mathrm{A} \square$ & $\mathrm{B} \square$ & $\mathrm{C} \square$ & $\mathrm{D} \square$ & $\mathrm{F} \square$ \\
\hline
\end{tabular}

